\title{
Palynological Studies in Fimbristylis and Eleocharis of Cyperaceae of Wardha District, Maharashtra, India
}

\author{
Kawarase A. D. ${ }^{1}$, Kunjalwar S. G. ${ }^{2}$ \\ ${ }^{1}$ Department of Botany, H. R. Arts and Science College Ashti, Dist. Wardha \\ ${ }^{2}$ Department of Botany, Nutan Adarsh Arts, Commerce and Smt. M. H. Wegad Science College, Umred. Dist. Nagpur
}

\begin{abstract}
There are advantages in using pollen grains as a valuable source of characters in systematic studies. Fimbristylis and Eleocharis are two important genera of Cyperaceae. In the present study Eight species of Fimbristylis and Three species of Eleocharis have been selected for pollen morphological studies. Pollen grains of Cyperaceae are oblate spheroidal to perprolate in shape, inaperturate to polyporate with opercula or pontopercula on pori or colpi.Apertures occur in all species investigated. Pollen morphological variation within Cyperaceae is considerable.
\end{abstract}

Keywords: apertures; Cyperaceae; exine; key;pollen; sedges; palynology

\section{Introduction}

Cyperaceae is the third largest family in the monocotyledons consisting of 109 genera and approximately 5,500 species (Govaerts et al. 2007). Recent phylogenetic studies based on molecular data have suggested to maintain only two subfamilies within Cyperaceae: Mapanioideae and Cyperoideae (Simpson et al. 2008; Muasya et al. 2008). In this new delimitation Mapanioideae comprise two tribes: Hypolytreae and Chrysitricheae, while the circumscription of Cyperoideae changed considerably to include taxa previously placed in Caricoideae and Sclerioideae (sensuGoetghebeur 1998)

The palynology of Cyperaceae attracted quite some attention in the past, mainly because of the occurence of an unusual type of simultaneous microsporogenesis, which leads to the formation of pseudomonads (Selling 1947; Davis 1966) or kryptotetrads (Erdtman 1952). After meiosis of the microspore mother cell, one of the four nuclei enlarges and occupies the centre of the coenocytic cell, while the other three nuclei migrate to the narrow apex where they are separated by septa and subsequently degenerate (Shah 1962; Dunbar 1973; Strandhede 1973; Furness and Rudall 1999; Brown and Lemmon 2000; Simpson et al. 2003). This unusual pattern of microsporogenesis is only known in one other unrelated group: tribe Styphelieae in Ericaceae (SmithWhite 1959).

Several authors have recognized different pollen types in Cyperaceae mainly based on pollen shape, pollen size, and number and type of apertures. However, the number of species investigated with scanning electron microscope (SEM) is very limited and the recent availability of a Cyperaceae phylogeny offers great potential for evolutionary interpretations of the data. The major aim of the present study is to provide a palynological overview at genera and family level in order to document with scanning electron microscopy, the pollen and orbicule morphology. Our data will be use to assess the taxonomically useful characters, and to determine palynological evolutionary trends in
Cyperaceae as Fimbristylis and Eleocharis are important genera with important pollen type as recognized in this study.

\section{Materials and Methods}

For pollen morphological study fresh material was collected. The matured anthers were collected and kept in small vials containing $70 \%$ alcohol. When the polliniferous material was taken from herbarium sheets, spikes were initially boiled in water for minutes, stamens separated and collected and preserved in $70 \%$ alcohol for at least a few hours before proceeding for acetolysis method of Erdtman(1952).

A total of Eight species of Fimbristylis and Three species of Eleocharis have been investigated in present study. The polliniferous material in the $70 \%$ alcohol was crushed with the help of glass rod for 2-4 minutes, shaken well and transferred to centrifuge tubes through a mesh (48 meshes/c.m. size). Pollen material was centrifuged at 3000 rpm. for 3 minutes and decanted off. In centrifuged pollen material, $5 \mathrm{ml}$ glacial acetic acid was added, again centrifuged and decanted off.

Acetolysis mixture was then poured in the tubes. The acetolysis mixture was prepared by taking 9 parts of acetic anhydride and 1 part concentrated sulphuric acid, added drop by drop. The tubes with the acetolysis mixture were stirred well and kept in water bath at $70^{\circ} \mathrm{c}$. The water was then allowed to boil for 2-4 minutes till the mixture in tubes turns golden brown in colour. The acetolysis mixture in tubes, after cooling was again centrifuged and completely decanted off. Then $5 \mathrm{ml}$ of glacial acetic acid was poured in the tubes, centrifuged, a mixture was made of $2 \mathrm{ml}$ of glacial acetic acid, 2-3 drops of saturated Sodium Chlorate/ Potassium chlorate solution followed by 1-2 drops of concentrated $\mathrm{HCl}$. Such prepared chlorination mixture was then poured in the tubes containing pollen material (Nair, 1960). During chlorination process, chlorine was evolved within few minutes, which bleached the pollen material. By this method the exine became clearly visible for observation. 


\section{International Journal of Science and Research (IJSR) \\ ISSN (Online): 2319-7064}

Index Copernicus Value (2013): 6.14 | Impact Factor (2015): 6.391

The mixture was then centrifuged and decanted off and then pollen material in tubes was washed with distilled water and centrifuged again. Finally dilute glycerine containing glycerine and distilled water in equal parts was added in the tubes. This mixture was shaken thoroughly in order to disperse the pollen equally. This is allowed to stand to 1 hour, centrifuged, decanted off and the pollen were mounted in the glycerine jelly.

\section{Observations}

\section{Eleocharis acutangula (Roxb) Schult}

Pollen LM. Heteropolar, asymmetrical, monocolpate, spherical, oval, size $47.5 \mu$ range $45 \mu$ to $50 \mu$, rather large, prolate, spheroidal, exine $2 \mu$ thick, exine surface reticulate, thinner.

Eleocharis atropurpurea (Retz.) Presl.

Pollen LM. Heteropolar, asymmetrical, monocolpate to bicolpate, spherical, size $42.5 \mu$ range $40 \mu$ to $45 \mu$, rather large, prolate, spheroidal, exine $1.5 \mu$ thick, faintly reticulate surface.

Eleocharis geniculata (Linn.) Roem \& Schult.

Pollen LM.Heteropolar, asymmetrical, tricolpate, spherical, size $42.5 \mu$ range $40 \mu$ to $45 \mu$, rather large, folded, prolate, spheroidal, granular surface.

Fimbristylis bisumbellata (Forsk.) Bub.

Pollen LM. Heteropolar, asymmetrical, monocolpate, oval, folded variously, size $42.5 \mu$ range $50 \mu$ to $35 \mu$, suboblate, exine $1.5 \mu$ thick, reticulate surface.

Fimbristylis cymosa $\mathrm{R} . \mathrm{Br}$.

Pollen LM. Heteropolar, asymmetrical, monocolpate, variously folded, ellipsoidal, size $47.2 \mu$ range $50 \mu$ to $45 \mu$, rather large, oblate, spheroidal, exine $1.5 \mu$ thick, granular surface.

Fimbristylis dichotoma (Linn.) Vahl.

Pollen LM.Heteropolar, asymmetrical, spherical, monocolpate, folded variously, size $50 \mu$ range, $40 \mu$ to $60 \mu$, rather large, prolate, exine $2 \mu$ thick, surface granular.

Fimbristylis ferruginea (Linn.) Vahl.

Pollen LM. Heteropolar, asymmetrical, monocolpate, folded variously, spherical, ellipsoidal, size $40 \mu$, range $45 \mu$ to $35 \mu$, medium, suboblate, exine $1.5 \mu$ thick, foviolate surface.

Fimbristylis miliacea (Linn.) Vahl.

Pollen LM. Heteropolar, assymetrical, mono-tricolpate, oval, folds prominent, size $37.5 \mathrm{u}$, range $35 \mu$ to $40 \mu$, rather large, prolate, spheroidal, exine $1.5 \mu$ thick, reticulate, foviolate.

Fimbristylis ovata (Burm.f.) Kern.

Pollen LM. Heteropolar, assymetrical, monocolpate, oval, spherical, variously folded, size $45 \mu$, range $45 \mu$ to $30 \mu$, rather large, suboblate, exine $1.5 \mu$ thick, granular surface.
Fimbristylis schoenoides (Retz.) Vahl.

Pollen LM. Heteropolar, assymetrical, monocolpate, oval, folded, size $57.5 \mu$, range $50 \mu$ to $65 \mu$, large, prolate, spheroidal, exine $1.5 \mu$, thick, reticulate surface.

\section{Fimbristylis tetragona $\mathrm{R} . \mathrm{Br}$.}

Pollen LM. (Photo Plate - 34 E \& F) Heteropolar, assymetrical, monocolpate, oval to spheroidal, variously folded, size $52.5 \mu$ range $45 \mu$ to $60 \mu$, large, exine $2 \mu$ thick, prolate, surface very clear foviolate exine surface.

\section{DISCUSSION}

The Cyperaceae is a subject of intensive researches because of peculiar course of pollen development. the pollen grains are called 'Pseudomonad' (Selling 1947), Cryptotetrad (Erdtman, 1952), or Monad (Cronquist 1968). The pollen morphology in the family has been studied by Wodehouse (1935), Erdtman (1952), Kuprianova (1948), Sharma (1967), Padhye (1966-1967), Nair (1970), Padhye and Makde (1980),Kunjalwar (2008).

While summarising the pollen-morphological investigations on Cyperaceae; Erdtman (1952) stated that the Cyperaceae shows two patterns of pollen, the Carex, and Cyperus type. Carex type is characterised by the presence of one ulceroid aperture at the thick end and three lateral faintly marked poroid or elongate apertures on the lateral sides, is the commonest aperture type in the family. In Cyperus type a prominent colpus is present at the broader end and it is the dominant character in the family.

The present study indicates that Eleocharis acutangula (Roxb) Schult., Eleocharis atropurpurea (Retz.) Presl., Eleocharis geniculata (Linn.) Roem \& Schult., Fimbristylis bisumbellata (Forsk.) Bub., Fimbristylis cymosa R.Br., Fimbristylis dichotoma (Linn.) Vahl., Fimbristylis ferruginea (Linn.) Vahl,. Fimbristylis miliacea (Linn.) Vahl., Fimbristylis ovata (Burm.f.) Kern., Fimbristylis schoenoides (Retz.) Vahl., Fimbristylis tetragona R.Br.show the Cyperus type of pollen. This is also the common aperture condition in many other Monocot families.

Erdtman (1952) who reported such a pattern in Mapania and allied genera, considered it somewhat puzzling for Cyperaceae. The present findings, however, clearly show that the monocolpate condition of the pollen in the family which appeared a puzzle to Erdtman (1952) is all the same quite dominant.

It thus appears that the Cyperaceae shows two patterns of pollen; the Carex and the Cyperus types. The later seems to be evolved from the former by elimination of lateral aperture and therefore more evolved. The faintly marked poroid or elongate apertures or colpoid streaks seen in various taxa showing Carex type (Erdtman 1952), Cyperus rotundus (Sharma 1967) and Pycreus latespicatus, P. puncticulatus and Cyperus imbricatus ( Padhye \& Makde 1980) lends further support to this contention.

The pollen of Cyperaceae possess thin exine that is scanty ornamented. Grains are often tenui-exinous with sexine as thick or slightly thicker than nexine (Erdtman, 1952). Mostly 


\section{International Journal of Science and Research (IJSR) \\ ISSN (Online): 2319-7064 \\ Index Copernicus Value (2013): 6.14 | Impact Factor (2015): 6.391}

LO Pattern is encountered though exceptionally LO Pattern is typically seen in Hypolytrium schraderianum. The present study confirms that exine stratification is simple, being mostly foveolate or granular.

Erdtman (1966) pointed out that the aperture type with one ulceroid aperture at the thick end and three lateral, \pm faintly marked poroid or elongate apertures, is the most frequent type within the Cyperaceae ( the Carex - type). He also stated that the genus Mapania and several others differ from the rest of the Cyperaceae because mapanoid pollen grains are spheroidal and only have one distinct aperture, an ulcus.

Haines and Lye (1983) translated this distinction into two major type, the Mapania - type (found only in the tribe Hypolytreae) and the Carex - type (found in vast majority of sedges).

Koyama (1961) distinguished three pollen grain types within the Cyperaceae.

(a) apple-shaped, $1+3$ or $1+6$ aperturate (most of the Cyperaceae);

(b) Spheroidal, polyforate (representative of the genus Machaerina);

(c) Spheroidal, inaperturate (representatives of the genus Hypolytrum).

Padhye \& Makde (1980) mentioned the monocolpate pollen grain type for Eleocharis capitata while Sultan et al. (1994) and van Wichelen et al. (1999) observed 4-aperturate pollen grains in this species. In the present findings monocolpate pollen grain is found in E.acutangula, present results do agree with Padhye \& Makde (1980) results but in E. geniculata,

E. atropurpurea monocolpate to tricolpate pollen grains are found.

Dahlgren \& Clifford (1982) stated that the majority of the pollengrains of Cyperaceae are ulcerate, with some of them still presenting 3 lateral pores or long thinnings.

More recently, van Wichelen et al., (1999), using LM and SEM analysis of representatives from the four sub families of Cyperaceae (Classification after Goetghebeur, 1986), singled out the groups of Mapanioideae (anaulcerate, frequently spheroidal \pm thick walled pollengrains). Sclerioideae - Caricoideae (anaulcerate with three lateral pores or colpi, mostly broadly obovoid and thin walled pollen grains) and Cyperoideae (anaulcerate with several lateral pores or colpi, mostly obovoid and thin walled pollen grains). The last of these groups appeared heterogeneous, perhaps distinguishable in species with lateral colpi and species with lateral pores.

Ontogeny of pollen grains in Cyperaceae is nearly unique among angiosperms (van Wichelan et al., 1999): microsporogenesis is simultaneous (Furness \& Rudall, 1999) and only one meiotic nucleus of a tetrad survives to form a pseudomonad (Selling, 1947) but these characteristics seem independent of the nature of the pollen grain wall (van Wichelan et al., 1999) and of aperture type (Furness and Rudall, 1999), respectively.

The pollen of Bulbostylis and Fimbristylis of the tribe Scirpeae are monocolpate. Exine in both the cases is faintly granular hence mereger of both the genera is justified as proposed by Koyama (1961), Padhye and Makde (1980). The present work on the species of Fimbristylis also testifies to this.

Up till now only fragmentary data on the morphology of pollengrains of Cyperaceae have been published. This data are often based on few genera or species and the resulting typologies are insufficient to answer the question whether pollen grain morphological characters could be of taxonomic value in the Cyperaceae.

\section{Photo Plate - 1}

\section{Pollen grains Light Microscopy}
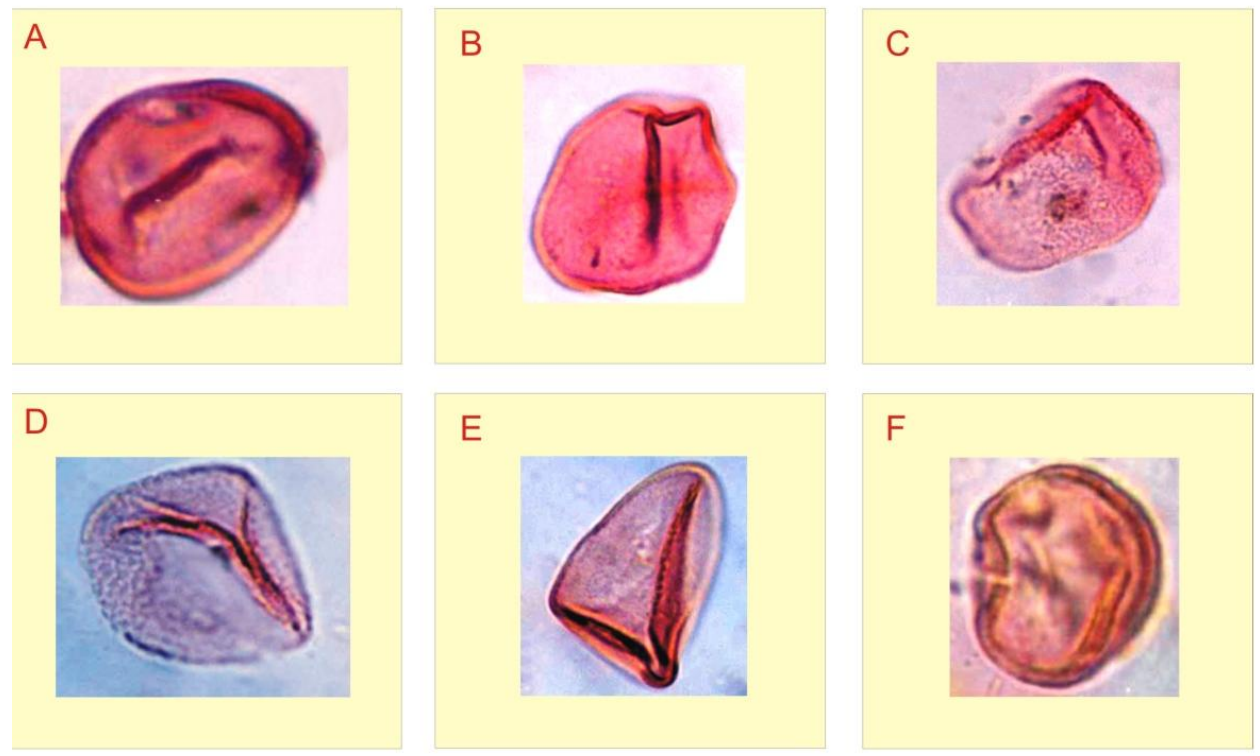


\section{International Journal of Science and Research (IJSR) \\ ISSN (Online): 2319-7064}

Index Copernicus Value (2013): 6.14 | Impact Factor (2015): 6.391
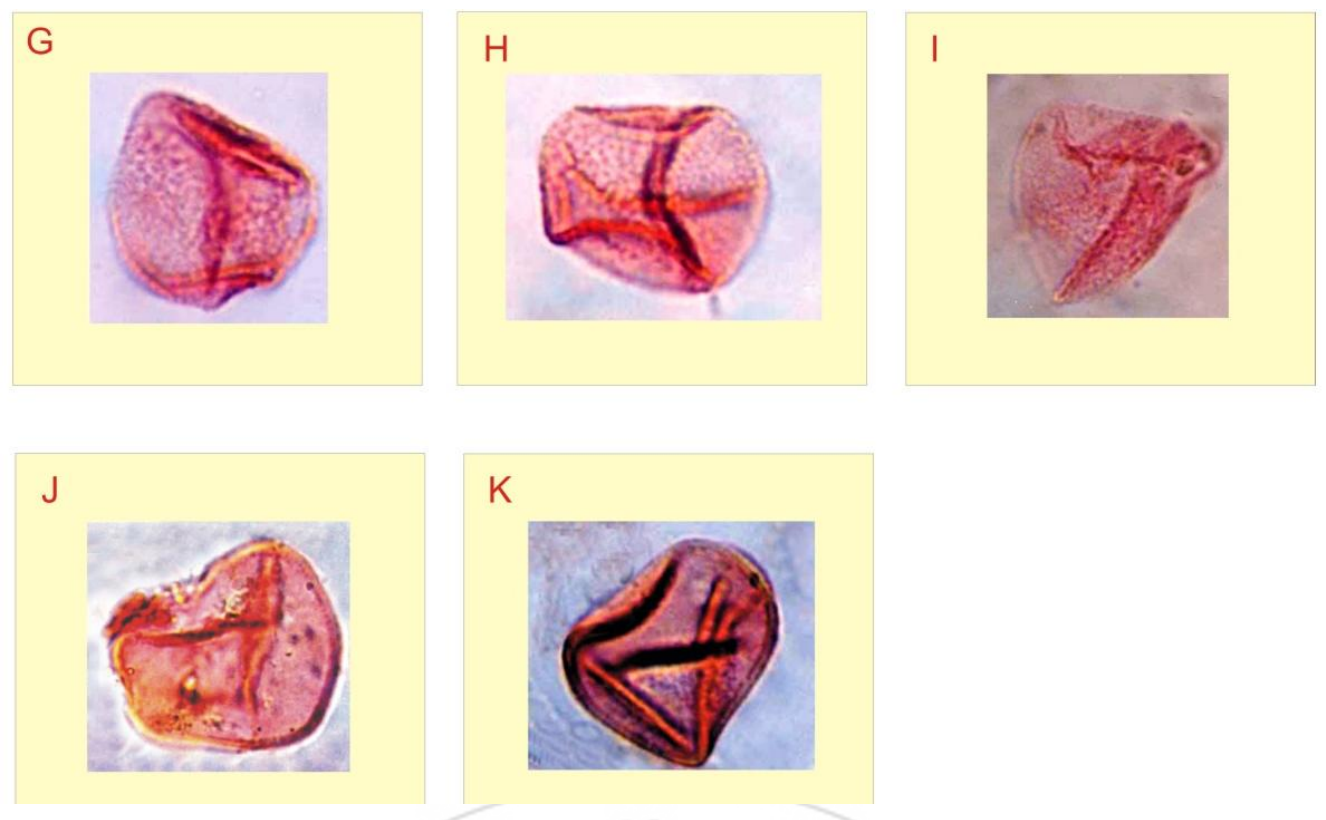

A. Eleocharis acutangula (Roxb) Schult., B. Eleocharis atropurpurea (Retz.) Presl.,

C. Eleocharis geniculata (Linn.) Roem \& Schult., D. Fimbristylis bisumbellata (Forsk.) Bub.,

E. Fimbristylis cymosa R.Br., F. Fimbristylis dichotoma (Linn.) Vahl.,

G. Fimbristylis ferruginea (Linn.) Vahl,. H. Fimbristylis miliacea (Linn.) Vahl.,

I. Fimbristylis ovata (Burm.f.) Kern., J. Fimbristylis schoenoides (Retz.) Vahl.,

K. Fimbristylis tetragona R.Br.

\section{References}

[1] Brown RC, Lemmon BE (2000) The cytoskeleton and polarization during pollen development in Carex blanda (Cyperaceae). Amer J Bot 87:1-11

[2] Bruhl JJ (1995) Sedge genera of the worldrelationships and a new classification of the Cyperaceae. Austral Syst Bot 8:125-305

[3] Cronquist, A. 1968 The Evolution \& Classification of Flowering plants Nelson, London. U.K.

[4] Dahlgren RMT, Clifford HT, Yeo PF (1985) The families of the monocotyledons. Academic Press, London

[5] Davis GL (1966) Systematic embryology of the angiosperms. Wiley, New York

[6] Dunbar A (1973) Pollen development in Eleocharis Palustris Group (Cyperaceae). 1. Ultrastructure and ontogeny. Bot Not 126:197-254

[7] Erdtman G (1952) Pollen morphology and plant taxonomy. Almqvist \& Wiksell, Stockholm

[8] Erdtman G (1966) Pollen morphology and plant taxonomy. Angiosperms.

[9] Hafner, New York.

[10] Furness CA, Rudall PJ (1999) Microsporogenesis in monocotyledons. Ann Bot 84:475-499.

[11] Goetghbeur, P. (1986) Genera Cyperacearum. Een bijdrage tot de Kennis van de morfologie, systematick en fylogenese van de Cyperaceae genera - DPhil. Thesis. State University of Ghent, Belgium.

[12] Goetghebeur P (1998) Cyperaceae. In: Kubitzki K (ed) The families and genera of vascular plants. Flowering plants-monocotyledons, vol 4. Springer, Berlin, pp 141-190

[13] Govaerts R, Simpson DA, Goetghebeur P, Wilson K, Egorova T, Bruhl JJ (2007) World checklist of
Cyperaceae. The Board of Trusteeds of the Royal Botanic Gardens, Kew. Available at http://www.kew.org/wcsp/monocots/, Accessed on 1 October 2007

[14] Haines RW, Lye KA (1983) The sedges and rushes of East Africa. African Natural History Society, Nairobi

[15] Koyama T. 1961 Classification of family Cyperaceae 1. J. Fac. Sci. Univ. Tokyo 8 (3). 37-148.

[16] Kunjalwar S.G.(2008) Scanning electron microscopy as aid to the taxonomy of sedges: sporoderm and spermoderm pattern in some Cyperaceae of Nagpur District,Ph.D. Thesis Rashtrasant Tukadoji Maharaj Nagpur Univrsity Nagpur.India

[17] Kuprianova, L.A. 1948 Pollen morphology and the phylogeny of the monocotyledons. Comm. Komorrow. Indst. Acad. Sci. 1:7.

[18] Muasya AM, Simpson DA, Verboom GA, Goetghebeur P, Naczi RFC, Chase MW, Smets E (2008) Phylogeny of cyperaceae based on DNA sequence data: current progress and future prospects.

[19] Nair P. K. K. (1970) Pollen morphology of Angiosperms. Vikas Publication, Delhi.

[20] Padhye M.D. (1966-67) The pollen grains of Kyllinga Rottb. Palynological Bull. vol. II \& III. pp. $101-103$.

[21] Padhye MD, Makde KH (1980) Pollen morphology of Cyperaceae. J Palynol 16:71-81

[22] Selling $\mathrm{OH}$ (1947) Studies in the Hawaiian pollen statistics, Part II. The pollens of the Hawaiian phanerograms. Bulletin of the Bishop Museum. Honolulu 38:1-360

[23] Shah CK (1962) Pollen development in some members of the Cyperaceae. Plant embryology - a symposium. CSIR, New Delhi, pp 81-93

[24] Sharma, M. 1967 Pollen morphology of Indian Monocotyledons J. Palynol Special Volume. 


\section{International Journal of Science and Research (IJSR) \\ ISSN (Online): 2319-7064}

Index Copernicus Value (2013): 6.14 | Impact Factor (2015): 6.391

[25] Simpson DA, Furness CA, Hodkinson TR, Muasya AM, Chase MW (2003) Phylogenetic relationships in Cyperaceae subfamily Mapanioideae inferred from pollen and plastid DNA sequence data. Amer J Bot 90:1071-1086

[26] Simpson DA, Muasya AM, Alves M, Bruhl JJ, Dhooge S, Chase MW, Furness CA, Ghamkhar K, Goetghebeur $\mathrm{P}$, Hodkinson TR, Marchant AD, Nieuborg R, Reznicek AA, Roalson EH, Smets E, Starr JR, Thomas WW, Wilson KL, Zhang X (2008) Phylogeny of Cyperaceae based on DNA sequence data-a new rbcL analysis. In: MonocotsIII/Grasses IV. Claremont, CA: Aliso 23: 72-83

[27] Smith-White S (1959) Pollen development patterns in the Epacridaceae. Proc Linn Soc NSW 84:8-35

[28] Strandhede SO (1973) Pollen development in Eleocharis Palustris Group (Cyperaceae). 2. Cytokinesis and microspore degeneration. Bot Not 126:255-265

[29] Sultan, S., Perveen, A \& Qaiser, M. 1994. A Palynological study of monocots from Karachi (excluding Gramineae ) - Pakistan Journal of Botany. 26 (1) : 21-34.

[30] Van Wichelen J, Camelbeke K, Chaerle P, Goetghebeur P, Huysmans S (1999) Comparison of different treatments for LM and SEM studies and systematic value of pollen grains in Cyperaceae. Grana 38:50-58

[31] Wodehouse RP (1935) Pollen grains. Their structure identification and significance in science and medicine. Hafner, New York

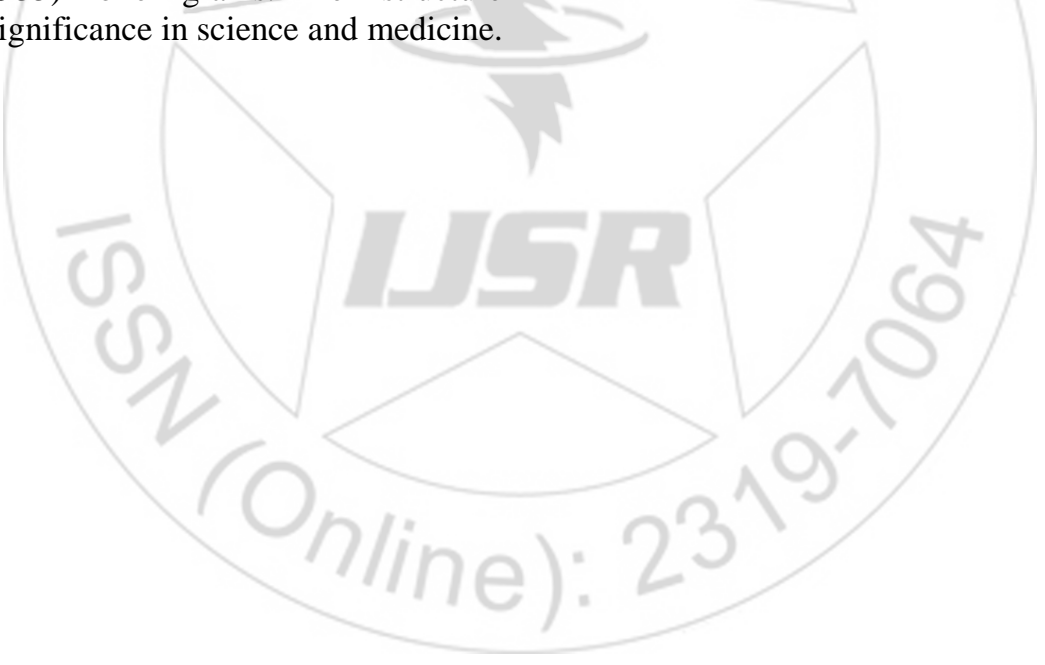

